Int.J. Hum. Soc. Dev. Res.

ISSN (P):2521-1439; ISSN (E):2523-4331

Volume 2, Number 1, 2018. 7-24

DOI:10.30546/2523-4331.2018.2.1.7

\title{
PAKISTANI DIASPORA IN BRITAIN: THE RECREATION OF HOMELAND SPACE
}

\section{Hassen Zriba}

University of Gafsa, Tunisia

\section{(C) The Author(s) 2018}

\begin{abstract}
Pakistani community is the largest ethnic minority in the British city of Bradford . Yet, it seems that such community resorted to specific cultural and residential patterns that could be understood as a process of creating and maintain a diasporic character. Such claim could be further confirmed by the fact that Brafordian Pakistanis tend to keep strong cultural and sanguine ties with other Pakistanis in Britain and in Pakistan itself. Cultural practices such as arranged marriages reveal that Pakistanis attempt to keep distinctive identity in the contemporary multicultural British society. Importantly, they perpetuate strong ties with the real or "imagined" homeland Pakistan and entrench strong sense of a common identity. Diaspora has come to the fore in cultural and ethnic studies. It is believed that the concept of Diaspora has become so central in understanding the way global ethnic minorities and communities interrelate and reinvent different spaces to respond to their specific needs. This article scrutinizes the British Pakistanis' diasporic practices in the city of Bradford. It is argued that South Asians in general and Pakistani community in particular did create, to a large extent, specific cultural spaces or comfort zones that keep recreating their "homeland experiences". The critical interpretative analysis of a wide range of local literature on the experiences of Bradfrodian Pakistanis reveals that Pakistani Diaspora is a true lived experience that tailored British native spaces to the cultural diasporic needs of British Pakistanis.
\end{abstract}

() 2018.All rights reserved

\section{ARTICLE HISTORY}

Received: 13/10/2017

Accepted: 02/02/2018

Published online: 01/04/2018

\section{KEYWORDS}

Diaspora, space, Pakistani

community, culture, ethnicity

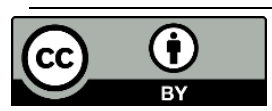

www.ijhsdr.com 


\section{Introduction}

Diaspora has come to the fore in cultural and ethnic studies. It is believed that the concept of Diaspora has become so central in understanding the way global ethnic minorities and communities interrelate and reinvent different spaces to respond to their specific needs. Thus the concept of space is vital in diasporic experiences. The concept of space has always been the scrutiny of a wide range of disciplines. Human beings have constantly tried to decipher the interrelatedness and omnipresence of such concept. Space seems to be inescapable; it is shaping our experiences and coloring our perceptions of both life and after-life. Space can be seen as the container of our experiences and its engine. Some utopian writers like Plato, Thomas More and Edward Bellamy, while trying to create utopian experiences in which the physical space loses its importance, set up their own fictionalized spaces. For instance, More's idea of "no place" is itself a new type of space. Whether physical or metaphysical, real or fictional, space seems to be a necessity. This article scrutinizes the British Pakistanis' diasporic practices in the city of Bradford. It is argued that South Asians in general and Pakistani minorities in particular did create, to a large extent, specific cultural spaces or comfort zones that keep recreating their "homeland experiences". The critical interpretative analysis of a wide range of local literature on the experiences of Bradfrodian Pakistanis reveals that Pakistani Diaspora is a true lived experience that tailored British native spaces to the cultural diasporic needs of British Pakistanis.

\section{The Diasporic understanding of the dialectics of space}

Jeff Malpas in his Place and Experience (1999) shows how place is so influential in shaping and expressing the individual's identity. Thus, human identity seems to be tied to a location whether real or imagined. Malpas asserts that: "The very structure of the mind is intrinsically tied to locality and spatiality" (1999: 10).

Basic to the idea of local space and delocalized space (global space) has been the concept of Diaspora. Such a process of creating and sustaining intra-community social cohesion and cultural sameness was theoretically captured by the concept of Diaspora. Steven Vertovec defined it as the 
"term often used today to describe practically any population which is considered 'deterritorialized' or 'transnational'- that is, which has originated in a land other than that in which it currently resides, and whose social, economic and political networks cross the borders of the nation-state or, indeed, span the globe" (1999: 1). The term, originally, used to refer to the Jewish experience of alienation and exile, has gained wide spread popularity and is used to refer to all communities that are dispersed and share certain cultural specificities that link them together. Robin Cohen provides in Global Diasporas (1997) the features that are common among groups that can be categorized as sharing a diasporic existence. The most important features are:

1.a collective memory and myth about the homeland, including its location, history and achievement;

2.an idealization of the putative ancestral home and a collective commitment to its maintenance, restoration, safety and prosperity, even to its creation;

3.a strong ethnic consciousness sustained over a long time and based on a sense of distinctiveness, a common history and the belief in a common fate. (Cohen, 1997: 26)

Vertovec identified emergent meanings of diaspora among South Asians in Britain. They are diaspora as a social form, a type of consciousness and a mode of cultural production. As a social form the concept of diaspora has been used by dispersed immigrants to construct social relationships by creating a sense of collective identity and belonging which are reflected in economic lobbies created within host societies to serve their immediate needs there as well as those of their homeland. Also, it is constructed politically through their loyalties and political orientations, divided between their country of residence and their homeland. Second, diaspora can be interpreted as a type of consciousness. It is so since it accelerates the process of identity formation and maintenance. Being aware of "multi-locality" (Vertovec, 1999: 8), immigrants develop malleable diasporic and hyphenated identities which stimulate and are stimulated by a need to be both here and there. So the concept of Diaspora seems to transcend the idea of local space and extend it to become a global one. Yet, Diaspora is by definition an exclusive notion sine it spans global threads people who are spatially and geographically dispersed but who share same culture epitomized by the sameness and commonness of past experiences (time). Thus, although such diasporic communities might not share the same past, they create their ideal perceptions of their "common past". 


\section{"Pakistanized" Bradford}

Central to the concern of this article is the idea that space is expressive and constitutive of human individual and collective identity. The terms "space" and "place" are used interchangeably here to refer to the physical and geographical locations of Pakistanis in Britain. This article accounts for the importance of a common heritage that social groups constitute and filter through the localities in which they live as well as through the creation of temporal dimensions (past) that can be adapted to their present needs. Ethnic residential segregation in Britain can be read as an indication of a collective tendency of ethnic groups to preserve their cultures and identities by setting limits for their residential space. Such limit setting is not only geographical but also cultural and psycho-social. Focusing on one ethnic minority (Pakistanis) and one specific locality (Bradford), it has become possible to show how the public space inhabited by such minority has been metamorphosed so as to express and maintain its own cultural needs. Pakistanis in Bradford are residentially concentrated in certain inner city wards such as University Ward, Bradford Moor and Toller in which they constitute the majority of residence (2001 Census). They seem to use the public space to project their collective identity. The process of Islamizing public space can be deemed as an example of how space is adjusted to their religious needs. British Pakistanis' cultural and residential patterns were considerably shaped by constraint factors such as racism and socioeconomic marginalization. Yet choice factors could not be relegated to a secondary position.

Choice theory was articulated by Dahya in his work 'The Nature of Pakistani Ethnicity in Industrial Cities in Britain' (in Cohen, 1974). He argued that choice factors were the most important determinants of ethnic urban segregation. According to him, there is an ethnic tendency to selfsegregate. Such a propensity, Dahya continued, is "voluntary and rational and irrespective of whether racial discrimination occurs or not" (Dahya: 112). The Pakistani self-segregation seemed to be a voluntary option in order to preserve Pakistani cultural practices and identity:

...the immigrant community's ecological

base serves several important functions, which are related to the community's need to create, manifest and defend its own identity. During the early stages of the 
community's settlement, the ecological base is closely interwoven with immigrants' participation in ethnic socio-economic institutions and mutual aid, and with the community's need to define its identity both for its members and outsiders. Reinforced by endogamy, the ecological base with its concomitant institution serves as an instrument for the transmission of the community's culture to the second generation and for maintaining ethnic boundaries and for avoiding (or minimizing) ambiguities with regard to ethnic diversity. (Dahya: 95)

As Dahya stated, cultural identity plays an important role in determining the ethnic minority's residential and social segregation and cluster. To preserve their cultural identity, ethnic minorities tend to recreate their home culture in the host society. They preserve strong ties with the homeland via a number of cultural practices such as chain migration, (Anwar, 1998), developing a 'Myth of Return' (Anwar, 1979), and arranging transnational marriages (Anwar, 1998). They seem to lead "sojourners lives" in the host societies.

Physical space, being a container of Pakistanis' experiences in Bradford, was to project a powerful desire to survive the host communities' essays of interference. Thus, Pakistanis, according to Deborah Phillips, developed an instrumental "strategy of avoidance" (2001: 3) which guaranteed the purity and safety of their identity. Some Pakistanis, commenting on their community concentration in inner city Bradford said that "in Manningham you feel safe, comfortable...you're with your own kind" (Ibid: 4).

Thus, Muslim Pakistanis in Britain and especially in Bradford have tried to recreate their homeland experiences within their new host community. Unlike other South Asian communities (e.g. Indians), Pakistanis developed their own residential patterns and seemed to take advantage of their residential concentration in inner city public space in Bradford in order to transform it from its initial secular and Christian aspects into religious and Islamic ones. They created, to use Herman Ouseley's phrase, "Comfort Zones" (2001: 3) in which they could practice their religio-cultural traditions.

As mentioned above, the notion of Diaspora promotes the development of a group identity at different levels (local, national and trans- 
national). However, the collective identity and communitarian traditions often require certain residential clustering and space tailoring. The old Islamic architecture required that a center of any newly-built village or town should be a mosque around which all aspects of socio-economic life are practiced. This religious requirement of residential concentration and the need to cooperate at all levels can easily enhance a mosque-centred residential pattern. The mosque plays socializing role and provides some socio-cultural and even economic support to its members. Virinder Singh Kalra (2000) showed how mosques in Bradford (example York Road Mosque) have an important function since they filled a major gap in the state's provision for unemployed, helping to temper the most negative aspects of unemployment and poverty. Logically, those who suffer from the impact of unemployment would seek the security and support of being within the community and, thus, they exist where the community exists. Moreover, mosques represent powerful and crucial symbols of Islam. They are seen as safe and secure Islamic spaces in what might be perceived as hostile and character-corroding environment. Thus, according to Sean Mcloughlin, "Mosques can provide secure religio-cultural continuity for those who have faced the dislocating experiences of migration and the social exclusion of racism and unemployment" (2003: 2).

The multitude of mosques' functions made their number increase excessively in a Muslim-dominated city like Bradford. According to Philip Lewis, the first mosque was opened in 1959; in 2001 the number jumped to 38 mosques in less than 25 square miles of inner Bradford which gives an idea about the concentration of Muslim in general and Muslim Pakistanis in inner city ethnic space in particular.

The president of the Bradford Council of Mosques Sher Azam assures that "there are 38 mosques with Friday prayer (plus another 22 which run education classes). We have education programs for our young people during the week and evenings where they learn their mother tongue and studied the Quran" (BBC News Online, 2003).

Apart from the socio-cultural function of residential proximity to the community with all its religio-cultural traditions, the communitarian and collectivist nature of the local Pakistani community in Bradford can instrumentally very beneficial. In 2001, the sociologist Roger Ballard provided insights into how cultural and sanguine relations help in employing local spaces of British Pakistanis to serve some diasporic trans- 
national needs. Ballard's article "The Impact of Kinship on the Economic Dynamics of Transnational Networks" was to show the extent of the functionality of South Asians' cultural patterns in their pursuit of economic prosperity. Ballard stressed mainly how the human and "cultural capital" of South Asians have "proved to be a very considerable asset" (2001: 9). Thus, according to Ballard, South Asians' kinship and cultural practices play a vital role in shaping their economic and residential choices. The feelings of "mutual reciprocity" ( 9) were expressed in the corporate character of the South Asian family, which created a sense of communitarian property, kind of economic communism. Such sense of spatial togetherness has been sustained by a sense of temporal homogeneity by which we mean that Pakistanis in order to set to coherent and cohesive communities in Britain, they tend to create idealized images of their homeland Pakistan and also they seem to be more conservative than Pakistanis in Pakistan. They seem to live in a "time capsule" in which they preserve traditions and customs that were metamorphosed in their homeland itself. British Pakistanis still cling to their past experiences and tradition in their homelands. Though different generations of the Pakistani community differ in their perceptions of the importance of Pakistan as a place and space of identification, they still stem much of their identities from Pakistan either as a real geo-cultural space or an imagined idealized one.

In Pakistan there is a social system of clan of caste (Braderi) ${ }^{1}$. Such system has emerged historically from local customs and family business traditions. Though younger Pakistanis have expressed their refusal of such system as an alternative to British social system, they recognized that it is an influential system of mutual expectations and traditional stratified relationships, which impacts on decisions made by their elders.

The post WWII migration, according to Ballard, was more than a mere mass movement of people who aspired to assimilate into the new host community. The chain migration and trans-national marriages were developed to sustain the traditional socio-cultural and economic structure. Family corporatism, arranged marriages and chain migration seemed to be geographically presented in Bradford by what Ballard called "colonybuilding" ( 10). They seemed to recreate, constantly, the circumstances of the first generation experience. Graham Mahony, a local race relations

\footnotetext{
${ }^{1}$ Biraderi is the patrilineal system in the Punjab. Cressy (2001) defined it as "similar to a clan or caste system [which] has emerged historically from local customs, land ownership patterns, family businesses and trades, and the influence of Hindu forebears." ( $p$ 5)
} 
expert in Bradford, commented upon such "colony building". He stated that, though the colonization of local space might hinder Pakistani community full assimilation into mainstream community; it proved to be a vital factor in preserving their identity and flourishing local ethnic market. There is an array of factors that have constrained Pakistanis' residential patterns in Britain. However, self-ascriptive forces played their role in determining residential choices. Pakistanis, like many other ethnic communities, established their own "ethnic enclaves" that seem to recreate their homeland environment.

\section{Pakistani cultural Diaspora in Bradford}

Though constraint factors have shaped the current Pakistani demographic distribution and degree of assimilation in the mainstream Bradford community, they are by no means the only factors which compelled the local Pakistani community to self-segregate and envision their self-made Diaspora. There are other factors which governed the Pakistani pattern of settlement. Those factors are called 'choice' factors, the aim of which was to keep Pakistani community religion, culture and ways of life intact. They are principally, Pakistani family organisation tradition, religious practices and marriage. Those issues are central for the local Pakistani community since they constitute the major components and indices of Pakistani tradition and identity. They mark the specificities of Pakistani Diaspora in Bradford in particular and Britain in general.

However, such cultural choices tend to stress the patterns of difference between Pakistanis and any other community. But, importantly, they can be a basis for socio-economic solidarity between the various members of the community locally, nationally and even trans- nationally (Ballard: 9).

Cultural difference has always been seen as a problem by the assimilationist model. Some of those who believed in this model conceived of Britain as "...a nation" composed of "a unitary whole, politically and culturally indivisible" (Mullard in Tierney: 120). Thus, cultural difference was seen as a threat to the social cohesion of a nation defined as homogeneous and stable. Consequently, new immigrants and their cultures and value systems were to be subordinated to the hegemonic idealized national culture. 
Nevertheless, the concept of 'culture' and its implications should be defined before scrutinizing Pakistani diasporic practices cultural values. The term 'culture' is defined broadly in sociology. It is most commonly used to delineate the symbolic aspects of human society (including beliefs, rituals, traditions, ideals or artistic creations). Culture, therefore, covers a wide range of social phenomena and social behaviour. For the aim of the present article, culture is used in its general meaning as the specific social characteristics, conventions, religious traditions and ways of life of a certain social group that differentiate it from other groups.

It is very important to note that cultural difference should not be seen as wrong. The host community's cultural patterns also represent a case of cultural difference for the newcomers. If whites are skeptical of non-whites' cultural difference - likely to be depicted and deemed as a 'deviation' from the norm - non-whites are equally skeptical of the host population's culture and way of life. Such a difference can be seen as a problem and is likely to create a confrontational context in which the hegemonic culture tries to dominate the subordinate one(s). In the process, xenophobic attitudes and racial stereotypes are formed and used as strategic tools to draw boundaries between different cultural groups.

In terms of the global values surveys done by Geert Hofstede and others, Pakistani culture and British culture are poles apart. Any binary portrayal would place them as opposites, for example in power distance, uncertainty avoidance, individualism and masculinity. In terms of power distance, Pakistan is a highly stratified society with a large difference between rulers and ruled, rich and poor, high caste and low caste people. Culturally, hierarchical relationships are rarely questioned, feudal practices persist and the current Government (2004) is a military dictatorship. Britain is also stratified but there is greater financial and class mobility and less of a power gap between rich and poor, rulers and ruled, and the current Government is democratically elected. British culture opts for rapid change supported by a limited need to reduce uncertainty because of the security of being able to rely on relative stability. On the other hand, Pakistani culture is more conservative as a strategy to reduce the uncertainty of life in a turbulent, vulnerable economic and military context. British culture is high on individualism; Pakistani culture is sympathetic to collectivism. British culture has moved away from masculinity in the $20^{\text {th }}$ century; Pakistani culture has not moved far in that direction, and, compared to British culture, is a very patriarchal, gendered culture. Though this bipolar opposition seems 
to be simplistic and reductionistic, it shows that Pakistanis in Bradford are likely to be seen as representatives of a different world. Their clinging to their ethnic identity, ethno-religious visibility and self-assertive practices can easily be interpreted as a threat to the host community's culture and values.

Three aspects of Bradford's Pakistani community cultural practices family organization, arranged marriage and religion - will be scrutinized and compared with the 'ideal' mainstream British cultural practices. These cultural traits constitute the gist of Pakistani Diaspora in Bradford.

\section{a) The Pakistani family}

The traditional family system in the Pakistani community is the joint/extended family. The joint/extended family consists of a group, usually of 3 or more generations, with a complex set of mutual obligations. For example, expenditure is controlled centrally and made from a common purse. This family system includes resembling relations, created by marriage, as well as those of descent. Brothers share land and other business, and work and live together. Another traditional type of family system is the 'stem family' system, whereby aged parents live with one of their sons and his wife and children, other sons having established their own households. The traditional joint household, in practice, divides into separate entities, each contributing labor and finance, and participating in the exchange of gifts and birth, marriage and death ceremonies. Anwar (1998: 100) offers other normative structural rules for the Pakistani family. They are the patrilineal descent group, patri-local residential rules, patriarchal authority and respect related to age and sex, and specific marriage patterns which keep the traditional family structure alive and lead to extended networks in the wider sense.

This traditional family system is still preferred by the majority of Pakistanis. According to a survey conducted by Anwar (1998) in 1975, 80\% of Pakistanis preferred to live in joint families. The same percentage $(80 \%)$ was found in 1983, which reflects the stability of such beliefs and preferences. Anwar identified two reasons for the continued preference of this family system: a traditional reason and a pragmatic one.

Traditionally, the joint/extended family system has been considered as a valuable cultural tradition inherited from the homeland. It is a crucial 
component of the Pakistani socio-cultural identity. Anwar (1998) concludes that

[T]he major reason for favouring the extended family was the fact that it was part of the traditional way of life and that it made for a happier family on which the individual member could depend in time of need. (104)

In addition, religious beliefs play a decisive role in feeding such traditional practices. Islam (the religion of the vast majority of Pakistanis in Bradford) encourages Muslims to keep close diasporic links with each other. It makes respect for elders obligatory. Such views have made young Pakistanis, generally, cling to their parents and live with them in the same household. In the 1975 survey, Anwar states a typical view of a Muslim young Pakistani to explain this: "Because of our religion. It says our parents are next to God (in terms of respect) and we respect them" (Ibid: 105).

The second reason is pragmatic. Children live with their parents because, simply, they love them. They also acknowledge their duty to look after them, particularly in old age. Moreover, such a traditional family system provides security, support and protection. Pakistani families live together so that they can help each other and feel socio-economically secure. There is evidence in Bradford of such a desire to live with parents and near to the community. A number of Pakistani young people echoed such a desire when interviewed by Phillips (2001): "In Manningham you feel safe, comfortable...you're with your own kind" (4). Though some young people wanted more freedom from the control of community and family, they still thought that it was crucial to keep a degree of proximity to their community and extended family; one respondent said:

I was born in this country, I've been brought up in this country, I've had all my education in this country. I don't want the culture to dictate how I am to live my life...so I don't want to be bang in the middle of the heart of the ...community. But I don't want to be too far away. (Phillips, 2001: 4)

It is also an opportunity for young Pakistanis to combine both the benefits of western individualism and the traditional Pakistani collectivism. Oscillating between two cultures, Pakistanis can get the best of both: 
individualists in mainstream society and collectivists in an extended family or community (Biraderi).

\section{b) Religion}

According to the 2001 Census, $16 \%$ of the Bradford population is Muslim. Given that the same data indicates that Pakistanis represent $15 \%$ of the population, it is probable that the vast majority of them are Muslim. The remaining $1 \%$ of Muslims is likely to be of Bengali or Indian origin.

It is clear that Islam is a primary identification for the Pakistani community, particularly the younger people. In 1998 the Commission for Racial Equality (CRE) did an attitudes survey, Stereotyping and Racism, in which all Muslims identified themselves first as Muslim and then tended to differ in allocating a nationality (hyphenated identities); younger people saw themselves as British whereas older ones thought of themselves as mainly Pakistani. Pakistanis felt that Islam was central to their identity, providing a moral and social framework for their lives and behavior, and that everything else was secondary. Typically, a Pakistani girl identified herself as "Muslim first, obviously. That's the most important, that's what you are" (10). Islamic spaces (mosques) provide religio-cultural continuity for those who had faced the experience of migration and the social exclusion of racism and unemployment. Some mosques in the Diaspora could be seen as reinventing the Islamic tradition within a completely different, sometimes hostile environment.

However, according to Jessica Jacobson, a considerable section of the Pakistani community uses the label Islam for social purposes only. They do not pray five times a day, nor are they all active in Islamic organizations. Islam seems to provide Pakistanis with a code for living that goes beyond narrow ethnicism. Thus, Pakistanis (especially the young people) resort to Islamic teaching to back their proposals for change. For example, they use Islam to support women's right to education and freedom to choose their husbands. Also, Islam has been used to connect different members of the community; it is used as the basis of community socialization.

Nevertheless, religion may be used (or rather abused) to construct images that mar the community image within mainstream society. Forced marriage is a good example of how Islamic teaching is distorted and cultural patterns given priority over religious ones. Yunas Samad, of Bradford 
University, did research to show how Islam could be used negatively to assert certain masculine values. He noted that, in the context of an already conservative Bradford macho male culture,

Islam... [P]lays a role in the construction of masculinity; ... [the young] project a 'hard' image of tough aggressive macho men... [and claim] membership of Hamas or Hizb-ut-Tahrir... Yet the same individuals were unaware who Shias were, and how they differed from Sunnis, and did not know what Hamas or Hizb-ut-Tahrir represent. Neither were they observant in their religious rituals.... and were quite often in trouble with the police for petty crime, drugs etc. Thus, the daubing of the walls...with the slogan 'Hamas Rules OK', or supporting anti-Semitic, homophobic and misogynist organizations such as Hizb-ut-Tahrir, was more an act of rebellion and defiance rather than the rise of 'fundamentalism'. It is all about being 'hard'...these affiliations seemed to be linked with territories....with Islamic nomenclature, such as Hamas, Hizb-ut-Tahrir or Tabligi Jamaaat [used] to [map and] define territorial control. (Samad, 1998: 425-438)

Obviously, such a negative use of Islam as a force for identity formation and preservation is likely to give credibility to anti-Muslim stereotypes, as being religiously insincere and manipulative. Kureishi's protagonist Riaz, in his The Black Album (1996), cried out in the mosque: "Rave from the Grave? Adam and Eve, not Adam and Steve. Islam: A blast from the Past or Force for the Future? And Democracy is a Hypocrisy" (Kureishi: 80). That type of language was likely to harm the public image of Muslims and Islam and reinforce xenophobic attitudes.

\section{c) Marriage}

One important aspect of Pakistani cultural specificity is marriage patterns. Marriage, according to Anwar (1998), cannot be seen as a contract between two individuals, a man and a woman. It is one that "binds families together and helps to maintain traditional customs" (106). The collectivistic 
nature of marriage is strikingly different from Western individualistic marriage.

Given the importance of marriage in protecting community unity and identity, the parents and relatives who arrange a marriage make sure that it remains intact and use family pressure to mediate in case of marital differences. The governing principle of marital choice seems to be homogamy - the selection of a partner from a similar social background, shaped, for example, by race, class, ethnicity, religion, age and education. Those who do not conform to these norms, in some circumstances, suffer sanctions, ranging from disapproval to ostracism (Bradford Commission Report, 1996). Compared to other ethnic minorities, only $1 \%$ of Pakistanis are married to a white partner. The figure is $20 \%$ for African-Caribbeans, 17\% for Chinese and 4\% for Indians (Modood and Berthoud 1997, pp 2930). Thus Pakistanis seem to follow the tradition of marrying within their social group.

According to Samad (2002), marriage is an important indicator of cultural distinctiveness and a basic means whereby boundaries are drawn to include or exclude those who are ineligible for marriage. Marriage is thus a strong tool to put diasporic strategies into practice. Group members, mainly elders and community leaders, try to maintain community social cohesion through sustaining a boundary between themselves and others. Thus, marriage outside the community represents a threat to internal social cohesion and breaks down boundaries and eradicates diasporic ties. It is a question of ethno-religious identity and belonging.

The 1991 British Social Attitudes Survey reported that 64\% of Pakistanis would mind strongly if one of the community was to marry a white partner, $54 \%$ of Indians disapproved, and $35 \%$ of Bangladeshis. But $75 \%$ of whites expressed their disapproval. As previously mentioned, marriage between Pakistanis is governed by various parameters. Central to them are cultural and religious sameness. The argument about custom and religion was explained by a Pakistani girl: "If the husband and wife belong to different groups, it would cause problems with customs and religion; if they belong to your own, no problems afterwards" (quoted in Anwar, 1998: 108). Moreover, arranged transnational marriages were favorably considered by the majority of Pakistanis since they "will offer their children a blend of eastern and western influence". Jay Bashir, a Pakistani man, said that "[B]ringing a girl from Pakistan means the kids will get better at both languages. I'll speak English and she'll speak Urdu, so they'll pick up both" 
(Vasagar). Thus arranged marriage, seen from this perspective, can be both a strategy for integration in the host society and for preserving Pakistani culture and language.

However, the persistence of the problem of forced marriage tends to create ambiguous images of Pakistani marriage patterns as a whole. According to Bradford's Asian Eye (2003), nationally 1,000 young British Asian women are said to be forced into marriage each year. In Bradford, the local police deal with about 70 cases annually. Apart from the causes of that type of marriage, they contribute to the creation of powerful images of Pakistanis as violators of basic human rights. The patriarchal structure of the Pakistani family is likely to invoke images of paternal dictatorship and domestic violence. There seems to be a violation of women's rights. Those perceptions can present the Pakistani community as alien to the British socio-cultural system. Thus, Pakistanis seem to represent all that the British are not. There seems to be a cultural mismatch between mainstream British values and those of British Pakistanis. Culture can act "as both an enabling and constraining force in the residential relocation process" (Phillips, 2002: 9 ). The desire to preserve a cultural heritage, combined with the socioeconomic functionality of such a heritage, can easily limit residential patterns. Ties to family, places of worship and other centralized community facilities often sustain a degree of inter-community continuity, usually expressed through geographical proximity.

\section{Conclusion}

Pakistani Diaspora is a lived experience in Bradford. Pakistanis developed specific socio-cultural ties among themselves in Bradford and Britain as a whole. Nevertheless, they also maintained strong ties with their homeland Pakistan via arranged marriages and the discourses of "Myth of Return". Locally, Pakistanis largely "opted for" residential concentration in inner city wards of Bradford. Importantly, such residential patterns whether they were a cause of ethnic marginalization and inter-ethnic conflict (the riots of 1995 and 2001), or they were the product of ethnic choices or host community constraints, it is very possible that the Islamization or more correctly the "Pakistanization" of public space in Bradford has been an attempt to cope with a real or perceived cultural invasion that might jeopardize the very foundations of Pakistani identity. Moreover, Pakistani Diaspora could be functionally kept intact via opting for the strategy of avoidance and the cultural and urban separateness. 


\section{Disclosure statement}

No potential conflict of interest was reported by the author.

\section{Contact Information}

E-mail: hassen_zriba@yahoo.fr 


\section{References and notes:}

Anwar, Mohammed. (1979).The Myth of Return: Pakistanis in Britain. London: Heinemann.

Anwar, Mohammed. (1998). Between Cultures: Continuity and Change in the Lives of Young Asians. London: Routledge.

Ballard, Roger. (2001). "The Impact of Kinship on the Economic Dynamics of Transnational Networks: Differential trajectories of adaptation amongst Mirpuris, Jullunduris and Sylhetis", Centre for Applied South Asian Studies, Manchester: Manchester University Press (http://www.casas.org.uk).

BBC News Online. (2003). "Rediscovering Islam" 20 November 2003, (http://bbc.co.uk/bradford/lifestyle/faith/personal_islam.html).

Boal, Frederick. (2001). "Urban Ethnic Segregation and the Scenarios Spectrum", International Seminar on Segregation in the City, Cambridge, Massachusetts: Lincoln Institute of Land Policy.

Bradford's Asian Eye (2003). "Why young want choice of partners", Newsquest Media Group, (http://www.thisisbradford.co.uk/asian_eye/ae-feat4.html).

Bradford Commission Report. (1996).The Report of an inquiry into the wider implications and public disorders in Bradford which occurred on 9, 10 and 11 June 1995. London: The Stationery Office (HMSO).

Bradford Council's Research and Consultation Service. (2001). First Key Census Statistics for Bradford District, compiled from (http://www.statistics.gov.uk/census2001/profiles/00cx.asp) and (http://www.neighbourhood.statistics.gov.uk). More local statistics can be found on (http://www.bradford.gov.uk/census2001).

Census in Bradford. (2001). "Your Community", City of Bradford Metropolitan District, from(http://www.bradford.gov.uk/bmdc/community and living/population)

Cohen, Robin. (1997). Global Diasporas: An Introduction. London: UCL Press.

Commission for Racial Equality CRE. (1998). Stereotyping and racism: Findings from two attitude surveys. London: Elliot House.

Cressey, Gill. (2001). "Followers of Tradition, Products of Hybridity or Bearers of Change: British Pakistani and Kashmiri Young People". Westhill: University of Birmingham.

Dahya, Badr. (1974). "The nature of Pakistani ethnicity in industrial cities in Britain" in A. Cohen (ed) Urban Ethnicity, London: Tavistock .

Hofstede, Geert. (1984). Culture's Consequences. London: Sage.

Kalra, Virinder. (2000). From Textile Mills to Taxi Ranks. Aldershot: Ashgate.

Kureishi, Hanif. (1996). The Black Album. London: Faber and Faber.

Jacobson, Jassica. (2001). "Religion and Ethnicity: Dual and Alternative Sources of Identity among Young British Pakistanis". Ethnic and Racial Studies 20-2, 238-56, 1997 in Cressey, G.

Mahony, Graham. (2001). "Race Relations in Bradford". Bradford: Bradford Vision, Section 7.

Malpas, Jeff. (1999). Place and Experience: A Philosophical Topography. Cambridge: Cambridge University Press.

McLoughlin, Sean. (2003) "Muslims and Public Space in Bradford: Conflict, cooperation and Islam as a resource for integration (file:///C/WINDOWS/Desktop/reports/puca/seanPuca.html) 
Modood, Tariq, Berthoud, Richard. et al. (eds) (1997). Ethnic Minorities in Britain: Diversity and Disadvantage. The Fourth National Survey of Ethnic Minorities. London: Policy Studies Institute.

Ouseley, Herman. (2001). Community Pride not prejudice: Making Diversity Work in Bradford. Bradford: Bradford Vision.

Phillips, Deborah. (2001). "The Changing Geography of South Asians in Bradford". Bradford: Bradford Vision, Section 5.

Phillips, Deborah. and Ratcliffe, Peter. (2002)“Executive Summary" in Movement to Opportunity? Leeds: University of Leeds, School of Geography.

Samad, Yunas. (1998). "Media and Muslim Identity: Intersections of Generation and Gender" in Innovation, vol 11. (4).

Samad, Yunas. and Eade, John. (2002). "Community Perceptions of Forced Marriage". London: Community Liaison Unit, Foreign and Commonwealth Office.

Tierney, John. (ed) (1982). Race Migration and Schooling. Hult: Rinehart and Winston.

Vertovec, Steven. (1999). "Three meanings of 'diaspora', exemplified among South Asian religions”. Oxford: Oxford University Press. 